\title{
Financial Architecture, Real Estate Market and Economic Development in Sub-Saharan African Countries: Evidence from Nigeria
}

\author{
Kehinde Adekunle Adetiloye and Patrick Omoruyi Eke \\ Department of Finance, Covenant University, Ota, Nigeria
}

Correspondence should be addressed to: Kehinde Adekunle Adetiloye;

kehinde.adetiloye@covenantuniversity.edu.ng

Received date: 7 October 2015; Accepted date: 13 December 2015;

Published date: 16 September 2016

Academic Editor: Aymen GHÉDIRA

Copyright (C) 2016. Kehinde Adekunle Adetiloye and Patrick Omoruyi Eke. Distributed under Creative Commons CC-BY 4.0

\begin{abstract}
This study examines the causal-relationship between financial architecture, real estate market and economic development in Nigeria. The Nigerian financial system may have performed creditably in the last few years there remains a major concern to developing Nigerian huge real estate market. Real estate phenomena, inclusive of its "green culture" and environmental planning and zoning system, may constitute a platform for achieving social and economic development objectives, such as: quality human capital, comprehensive and quality health system, increasing national productivity, serene and quality environment, balanced demography and optimal population growth, as hallmarks of the Millennium Development Goals (MDGs) in 2015. The aforementioned gap suggests a vacuum in the Nigerian development paradigm. Findings from this study suggest that the Nigerian financial structure has impeded the development of Nigerian real estate sector, hence, has accentuated the poverty syndrome of its citizens. The study suggests the financial "matching principle", where market driven financial institutions commit to long term funding, such as the Sovereign Wealth Funds, Pension Funds, etc, invest in mortgages and real estate development; the government should also commit higher capital budgetary allocations for infrastructural development. Finally, the government should set up construction bank, adopt responsive macroeconomic policies that would nip inflation rate, overhaul the Federal mortgage institutions and improve people" savings culture.
\end{abstract}

Keywords: Capital expenditure, Financial architecture, Real Estate Market, Economic Development

Cite this Article as: Kehinde Adekunle Adetiloye and Patrick Omoruyi Eke (2016)," Financial Architecture, Real Estate Market and Economic Development in Sub-Saharan African Countries: Evidence from Nigeria" ,Journal of South African Business Research , Vol. 2016 (2016), Article ID 494162, 


\section{Introduction}

Real estate as an integrated and interlocking conglomerate of discipline requires synergistic links for the purpose of enabling the sector to provide the vehicle for creating sustainable and liveable cities that have vibrant economies. The availability of valued properties and their marketing are regarded perhaps as the basis of the entire economic and social phenomena in the industry, acting as a mechanism through which values are created and the "goods and services are voluntarily exchanged among different owners" (Miller and Geltner, 2005).

For income, real estate is expected to provide a better return compared with its investment peers. Few forms of investment have weathered the storm of loss in purchasing power as real property. On value gain, it is also acknowledged that a prospective owner, or manager, can rehabilitate, upgrade, expand, or even reorient how a property is used, which ultimately adds value to the property. Other advantages include the tax advantage, especially in a regime of accelerated depreciation. Landed properties, as tangible assets serve as collaterals for lending, apart from the pride of ownership.

The downside effect of real estate investment has been illiquidity, as it might be difficult to convert the asset to cash. However, owners can result to a forced sale sometime at ridiculous prices. Where interested buyers appear, financing is a major issue. Wiedemer and Goeters (2003) note that when property is "encumbered with existing financing, the buyer must either refinance the property or obtain a secondary mortgage loan", and both procedures consume considerable time and effort. Additional to the liquidity problem results in the need to hold on to the asset for several years in order to realize the best possible return. Losses from fire, flood, and vandalism can be indemnified through insurance, but not all risks are covered.
A vital feature of real estate is location, which is an important factor affecting real estate value. Brueggeman and Fisher (2005) apt that successful real estate investors must realize that location as viewed by user-tenants as pertinent, and that business operations of potential tenant-users and how certain locations appear to those users are all equally important. Ukpong (2013) also asserts that developments in cities are organic, "they evolve, they grow, they consolidate, and after consolidating, nobody remembers the time it was just growing".

A maladapted financial system has been aptly adduced to Nigerian and other similar sub-Saharan underdeveloped economies, constituting greater obstacle to the long run development quest. Some characteristics of the financial system include, wide spread between deposit and lending rates, high rate of financial and economic restrictions and repression, inappropriate policy framework, weak institutions, poor regulations, government control rather than private led economies etc. All these are evident in the sluggish growth of the Nigerian economy, which had manifested since the mid-1980s. Whenever any major financial crises happen, the time lag is usually long for the economy to pick pace with other economies in a cyclical turnaround (Ndanusa, 2013).

The Nigerian financial architecture describes the financial system, structures, major instruments, and markets. Ojo (2010: 52) reveal that very important determinants of the effectiveness of the financial structure is "its structural characteristics, and the laws, regulations, and customs that govern its behaviour;" apart from the individual qualities of its financing institutions. It also describes the fiscal and monetary policies that operate at cross-purposes domestically and both must sustain investment (World Bank, 2010). Factors responsible for increasing real estate development are the acceleration in urbanization, rising income of the people: as more people can afford property, the demand becomes more effective pulling out resources for development of more real 
estate. Globalization and the ability to attract foreign direct investments (FDI); commercialization, industrial concentration; macroeconomic management of variables like the country's interest rate, exchange rate, inflation rate, tax policies and money supply also constitute actual and latent factors that impact and direct real estate development.

In this paper, we hypothesise that: the Nigerian financial architecture does not significantly enable the real estate development; secondly, there is no relationship between poverty syndrome and real estate development in Nigeria; thirdly, the mortgage system does not significantly impact real estate development. The rest of the paper is arranged as follows. Following after this introduction is the theories and literatures review, then the theoretical framework and methodology. Results and discussion is the fourth section while the last section concludes and recommends on the study.

\section{Theories and Literature Review}

The appalling state of real estate financing system in Nigeria is unfortunately replicated in the dearth of literature on the subject matter as most of the literature focuses on the housing sub-sector of real estate. It is noted that fields of housing economics are narrower in scope, concentrating on residential real estate markets while the research of real estate trends focuses on the business and structural changes impacting the industry. Plaut (1987) and Henderson and Ioannides (1979) note that most residential investments are undertaken to promote both consumption and portfolio investments. However, an optimal consumption/portfolio of investment decisions would depend on the investor's need for income and existing residential housing supply-demand structure (Jayaraman and Gebremedhin (2013), public policy and other macroeconomic variables.

The problems with housing industry have caught the attention of successive governments in Nigeria without any fundamental solution. Literature has always expressed concern about the appalling state of housing development and the entire construction industry in Nigeria, chiefly adduced to the gap between demand and supply in finance. The country's financial misfortune started few years after 1970 , following the unfortunate economic crises that accompany the jettisoning of the agro-based economy for the petro-based economy (Nubi, 1991). Ojo (2010: 67) adduced the reason for the Nigerian financial system's failure in the financing of post-independence development to the "conservatism of the financial system: a situation that remains virtually unchanged over four decades after". Building on the empirical innovations of the structural pattern of financial development, Goldsmith (1969) and (1971), Ojo apt that "information gap", "availability of funding gap", high cost of raising funds and inability of supply institutions to be effective in meeting the needs are partly responsible for Nigeria's poor financial architecture.

Studies have adduced that there is a long run equilibrium relationship between housing price and macroeconomic fundamentals such as population, national income, cost etc. Various reasons were adduced why the mortgage industry blossoms in the other parts of the world but still remains a mirage in Nigeria. Windapo (2000) and Okupe (2000) apt that the gap between the income and shelter cost among Nigerians is too wide, creating increasing demand-supply gap crises. This has eliminated the low-income earners from the housing market. Nubi (1991) had attributed the increasing high cost problem to the following: rising cost of building materials, inflation rate in the economy, high space and quality standard adopted by designers, fees of professional involved in housing designs and construction, excessive profit of contractors and tardiness of the National Housing Fund (NHF).

The nation's land use system and land acquisition cost are also big challenges for housing ownership and real estate development. The cost of processing title 
document is exorbitant and also a major concern. Perfecting land documents takes minimum of two years and is costly. Cost of land and documentation accounts, in most cases, for about half of the cost required for housing development (Nubi, 1991).

Jayaraman and Gebremedhin (2013) reviewed the works of Leung (2004), Turner and Luea (2009), Ofori and Han (2003), Arku and Harris (2005), Carruthers and Mulligan (2005) Carruthers and Mulligan, (2008)) on the multiple impacts of real estate on employment and income, household saving, labour productivity, health productivity and growth from real estate investment, as well as home ownership effects respectively, in the U.S. economy and found correlations between these variables.

Bischoff (2012) studied Germany cities with cross-sectional data, using 2SLS to model the impact of exogenous changes on prices, income and population, showing the positive effect of population on residential real estate investment and income. The outcome reveals significant correlation between income and real estate prices. The lack of viable construction industry and development companies is also adduced as challenging to the real estate sector in Nigeria. To Zubairu (2000), "the absence of large real estate development companies with access to the relevant technology and financial muscle to develop cheap houses on mass scale for the urban poor is a drawback to our housing delivery system". The construction industry also witnesses dearth of professionals resulting in several building collapses in several parts of the country, with only the multinational firms enjoying the best skills in the industry. Nubi (1991) also identified lack of alternative technology in core building material as a drawback; that "bricks are more expensive than blocks; the reliance of more builders on imported conventional building materials has led to high cost of construction, thereby compounding the problem of affordability". The emergence and growth of primary mortgage institutions (PMIs) to serve the need of housing delivery in all parts of Nigeria; and to collect, manage and administer contributions to the National Housing Fund (NHF) in accordance with the provision of the NHF Decree No. 3 of 1992 (Sanusi, 2003) seems not to have worked.

The 2011 new Nigerian National Housing Policy (NHP) reinvigorated the maiden policy adopted in 1991.The policy now sees the private sector arm of the economy as the "engine" responsible to providing solution to the wide supply gap in housing delivery to the citizen. The aims of the NHF as contained in Sanusi (2003) are: "encouraging a multiplication of housing finance institutions, enhancing mobilization and growth of long-term funds and making loans affordable to more borrowers". Other objectives of the fund include: ensuring constant supply of loans to Nigerians for the purpose of building, purchasing and improvement of residential houses, providing incentives for the capital market to invest in property development, encouraging the development of specific programmes that would ensure effective financing of housing development and to provide long-term loans to mortgage institutions for on- lending to contributors to the fund. It also aims to insulate the housing finance system from the volatilities associated with past reliance on government intervention.

To realize this, the 2011 Policy demanded the elimination of the following constraints militating against the realization of the private sector to efficiently deliver the mass housing functions as follows: difficulties in land acquisition and transfer caused by the provisions of the Land Use Act; difficulties in accessing long-term housing finance; difficulties posed by the non-enforcement of planning laws and regulations; threat posed environment control laws and regulations; shortage and high cost of building materials; scarcity of skilled manpower in the building industry; lack of sound policies and where they exist, the retrogressive effect of constant changes and inconsistencies; and lack of incentives and inducements.

The National Housing Policy (2011:55) also identified the following challenges associated with housing finance as: non- 
availability of long term funds to individuals, financial institutions and estate developers all of who require long term funds; Fund mismatch, that is, the use of short term funds for long term lending; Intermediation in housing finance is extremely sensitive to inflationary environment which results in high cost of borrowing, given its long term nature; Limited ability to mobilize resources effectively for low income, and medium income housing; Absence of a strong secondary mortgage market player for the purpose of taking out mortgages originated in the primary market, lack of uniform mortgage under writing standards; dearth/paucity of conforming mortgage assets, absence of a mechanism for effectively mobilizing and channelling construction finance; and absence of a National collateral Registry.

The National Housing Policy (2011: 63) similarly blamed the national macroeconomic factors as major reasons for upward trend in the cost of basic building materials leading to high construction and labour cost. Others are: increase in import duties on construction plant and machinery; the depreciation of the Naira vis-a vis other currencies; inadequate and inefficient infrastructural facilities (roads and rail transportation, water, sanitation, power supply etc); absence of new building materials' factories due to high cost of finance; lack of consistent policy formulation and implementation, which makes long term planning impossible; over-priced contracts; over-priced cost of production (caused by oligopolistic price-fixing); shortage of skilled manpower; increase in labour (artisans, etc.) cost; and absence of effective indigenous technology for the production of building materials.

Adedokun et al (2011) assessed the performance of the National housing fund for housing delivery, including the role of Federal Mortgage Bank and the Primary Mortgage Institutions (PMIs) using a nonparametric procedure. The paper arrived at the following conclusions: that the National Housing Fund scheme has not contributed significantly to the provision of housing accommodation to the citizen right from the inception of the scheme. Existing unfavourable environmental conditions prevent wide spread of existing PMI's and the emergence of the new ones across the states to enable contributors of the fund to assess loan for development purposes. Thus, other than the 4-stage least square works of Jayaraman and Gebremedhin (2013), the theoretical exposition of Nigeria's mortgage industry by Sanusi (2003), and of t late the work by Adedokun et al (2011) in Nigeria, no other work to the knowledge of this study has analysed the joint relationship between real estate development, financial sector development and economic development simultaneously particularly for the Nigerian economy. However, Adetiloye (2013) used the 2SLS to explore the relationship between mortgage finance and capital formation in Nigeria and found that the PMIs have failed in impacting capital formation.

\section{Theoretical Framework and Methodology}

Given the above theoretical and literature reviews, and the influence of interactions between variables such as real estate development relative to Gross domestic product(GDP), financial sector development, economic development, gross domestic product, gross fixed capital formation, and gross national savings, the applicable methodology for this paper is the three-stage least square. The threestage least square (3SLS) is a system method which is applied to all the parameters in the equations simultaneously. Developed by Theil and Zellner (1962), as "a logical extension of Theil's 2SLS, it involves the application of the least square in three successive stages" (Koutsoyiannis, 1977: 474).

The focus of this study is to analyze the relationship between real estate development, financial development and economic development represented by changes in real estate ratio of gross domestic product, financial sector ratio to GDP, and human development index. This method builds on the earlier work of Adetiloye's (2013) two stage least square, 
Jayaraman and Gebremedhin (2013) 4stage least square models which studied the role of residential real estate on capital formation and economic development in Nigeria and the United States respectively. Jayaraman and Gebremedhin (2013) built on the work of Deller et al's (2001) 3SLS by studying the interaction between population, employment, income and residential real estate. Data were sourced from World Development Indicators (WDI), Central Bank of Nigeria Statistical Bulletin, National Bureau of Statistics, United Nations Development Programme statistics, from 1975 to 2011.

\section{The Model and its Specification}

A common phenomenon in economic and business relations is that there are situations where a two-way channels of influence among economic variables, such as that one economic variable(s) affects another economic variable(s) and is, in turn, affected by it (them) (Gujarati and Smith, 2009: 671). Due to several variables correlating with the real estate development in the Nigerian economy, a parsimonious principle was adopted based on economic intuition (Gujarati and Porter, 2009:42) resulting in the three stage least square equations. Implicitly, the model is as follows:

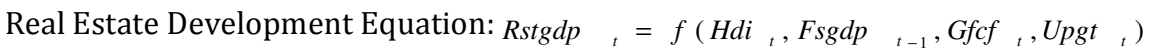

$$
\begin{aligned}
& \text { Economic Development Equation: } H d i_{t}=f\left(\text { Rstgdp }_{t}, \text { Gdprt }{ }_{t}, \text { Umrt }_{t}\right) \\
& \text { Financial Development: } F s g d p_{t}=f\left(\operatorname{Rsgdp}_{t}, \mathrm{Snrt}_{t}, \mathrm{Mpr}_{t}\right)
\end{aligned}
$$

Where: Rstgdp is real estate ratio of gross domestic product in Nigeria as proxy for real estate development; $H d i$ is human development index, the composite variable for human development comprising per capita income, literacy rate and life expectancy. This indicator proxies quality of life which real estate system could improve; Fsgdp is financial sector ratio of gross domestic product, a proxy of financial development, being financial assets deployed for real estate development; $G f c f$ is gross fixed capital formation, a proxy for the nation's capital stock to build economic infrastructures; Upgt is urban population growth rate; Gdprt represents gross domestic product growth rate, Umrt is unemployment rate; Snrt is savings rate, a proxy for deposit mobilization; $M p r$ is monetary policy rate, represents macroeconomic variable, which is a major determinant of the economy's lending capacity. It is proposed that real estate mechanism backed by appropriate financial structure is a panacea for economic development and vice-versa.

Intuitively, the relationship between real estate development, financial architecture and economic development cannot be linear. Neoclassical and financial theories through various models that demonstrate input- output relationship for growth/development exhibit characters that are non-linear in nature (Solow, 1956; Romer, 1986; Romer, 1996; Grossman and Helpman, 1991, etc). Thus, the explicit functional form of the model is:

$$
\begin{aligned}
& \text { Real Estate Equation: } \operatorname{sstgdp}_{t}=\beta_{0} H d i_{t}^{{ }^{\beta_{1}}}, F s g d p_{t-1}^{\beta_{2}}, G f c f t_{t}^{\beta_{3}}, \text { Upgt }_{t}{ }^{\beta_{4}}, \mu_{t} \\
& \text { Economic Dev. Equation: } H d i i_{t}=\alpha_{0} R s t g d p \quad{ }_{t}^{\alpha_{1}}, \text { Gdprt }{ }_{t}^{\alpha_{2}}, \text { Umrt }{ }_{t}{ }^{\alpha_{3}}, \psi_{t} \\
& \text { Financial Development: Fsgdp }{ }_{t}=\lambda_{0} \operatorname{Rsgdp}{ }_{t}^{\lambda_{1}}, \operatorname{Snrt}_{t}{ }_{t}^{\lambda_{2}}, \mathrm{Mpr}_{t}{ }^{\lambda_{3}}, \varepsilon_{t}
\end{aligned}
$$

Taking log Transformation of these equations produce the following linearized form

$$
\begin{gathered}
\text { InRstgdp }{ }_{t}=\operatorname{In} \beta_{0}+\beta_{1} \text { InHdi }_{t}+\beta_{2} \text { InFsgdp }_{t-1}+\beta_{3} \text { InGfcf }_{t}+\beta_{4} \text { InUpgt }_{t}+\mu_{t} \ldots . .(7) \\
\text { InHdi }_{t}=\text { In }_{0}+\alpha_{1} \text { Rsgdp }_{t}+\alpha_{2} \text { Gdprt }_{t}+\alpha_{3} \text { Umrt }_{t}+\psi_{t}
\end{gathered}
$$


InFsgdp $t_{t}=\operatorname{In} \lambda_{0}+\lambda_{1}$ InRstgdp $t_{t}+\lambda_{2}$ InSnrt $t_{t}+\lambda_{3} \operatorname{InMpr} t_{t}+\varepsilon_{t} \ldots \ldots \ldots \ldots \ldots \ldots \ldots . . . .(9)$

The a-priori expectations for the number of missing exogenous variables $M$, coefficients are as follows: $\beta_{0}, \beta_{1}, \beta_{2}, \beta_{3}, \beta_{4}$, must be greater than or equal to the $\alpha_{0}, \alpha_{1}, \alpha_{2}, \lambda_{0}, \lambda_{1}, \lambda_{2},>0 ; \alpha_{3}, \lambda_{3}<0$. First, the number of endogenous variables $G$ in the identification conditions of the system less one, indicating over-identified simultaneous equations were established; thereafter the reduced form of the model was obtained. The necessary (order) condition for identification requires that in an equation of the simultaneous model, the or exactly-identified respectively, otherwise it is under-identified (Asteriou and Hall, 2011: 236). Algebraically, this is stated as:

\section{$M \geq G-1$}

Where $M$ represents a number of exogenous variables missing from a particular equation under study, and $G$ is the number of endogenous variables in the system. Applying this to the simultaneous equations model above, the study achieved over-identification for both equations. The sufficient (rank) condition was evaluated, that is, the order of the largest nonzero determinant that is formed from the square sub-matrices is at least $G-1$ (Asteriou and Hall, 2011:237; Kmenta, 1997: 664; Gujarati and Porter, 2009:702). This was achieved, hence the estimation using the two- stage least square model (2SLS).The instruments used for the system's regression are UPGT GDPRT-1 RQTY SNRT1 MPR GFCF-1 HDI.

\section{Model Estimation method}

This study applies time series econometrics for Nigeria for the 1975-2011 period, and utilised 3SLS (three-stage least squares) estimation techniques. Gujarati and Smith (2009:730) claim that the basic idea behind the 2SLS method is to replace the (stochastic) endogenous explanatory variable by a linear combination of the predetermined variables in the model and use this combination as the explanatory variable in lieu of the original endogenous variable. The 2SLS method thus resembles the instrumental variable method of estimation in that the linear combination of the predetermined variables serves as an instrument, or proxy, for the endogenous regressors. The Three-Stage least square is the two-stage version of the seemingly unrelated regression (SUR) method. It is appropriate technique when right-hand

side variables are correlated with the error term, and there is both heteroskedasticity and contemporaneous correlation in the residual (Oyinlola, 2012).

One basic strength behind using 3SLS (three-stage least squares) is that the 2SLS is a single equation estimation method and it is a type of limited information method because it ignores information in the other equations (Karagol, 2002). The basic strength of 3SLS is that it takes into account the information-contained in the of-diagonal elements of covariance matrixes. Thus, 3SLS is asymptotically more efficient than 2SLS (Oyinlola, 2012; Judge et al., 1988). Koutsoyiannis (1977) states that it applies the method of least squares in three successive stages, by employing more information than the single equation techniques simultaneously. That is, it takes into account the whole structure of the model with all restrictions that this structure imposes on the values of the parameters.

\section{Other estimations techniques and Diagnostic Tests}

\section{Unit Root test}

A necessary prerequisite for testing the existence of cointegration in a set of variables is to carry out the stochastic trend test in the autoregressive representation of each variable time series. They ought to be integrated of same order for the technique of cointegration to be used. Using the ADF test, the order of integration (unit roots) of all the variables 
series was examined at level $\gamma_{t} \sim \mathrm{I}(0)$, that $\gamma_{t} \sim \mathrm{I}(\mathrm{n}) ; \mathrm{n}>0$, while at first difference $\Delta \gamma_{t}=\gamma_{t}-\gamma_{t-1}$.If yes $\gamma_{t} \sim \mathrm{I}(1)$. We uncovered that all variables were integrated of order 1 at both $1 \%$ and $5 \%$ Mackinnon (1996) critical level. We preferred the ADF to similar techniques (Philip-Perron (pp), Phillip and Perron $\Delta Y_{t}=\gamma Y_{t-1}+\sum_{i=1}^{p} \beta_{i} \Delta Y_{t-i}+e_{t}$ $\Delta Y_{t}=\alpha_{0}+\gamma Y_{t-1}+\sum_{i=1}^{p} \beta_{i} \Delta Y_{t-i}+e_{t}$ $\Delta Y_{t}=\beta_{0}+\beta_{1 t}+\gamma Y_{t-1}+\sum_{i=1}^{p} \beta_{i} \Delta Y_{t-i}+e_{t}$

Where $Y$ is a time series, $t$ is a linear time trend, $\Delta$ is the difference operator, $\partial_{0}$ and $\partial_{1 t}$ represent the presence of deterministic elements (constant and trend), $p$ is the optimum number of lags in the dependent variable and $e_{t}$ the random error term. The additional lagged term are also included to ensure that the errors are uncorrelated. The null hypothesis defines that variable $Y_{t}$ is a non-stationary series

$\left(\mathrm{H}_{0}: \gamma=0\right)$ and rejected when $\gamma_{0}$ is significantly negative (Ha: $\gamma<0)$.
(1988), because it relies on rejecting the null hypothesis of unit root (that the series are trended) in favour of the alternative hypothesis of non-trended or stationary variables. The general three possible form of the ADF respectively estimable are of the following regression forms:

\section{Granger Causality Test}

Causality relates to the ability of one variable to predict (and therefore cause) the other (Asteriou and Hall, 2011). Granger developed a VAR model that expresses both unidirectional and bidirectional feedback relationship between two variables $Y_{t}$ and $X_{t}$ estimated as follows:

$$
\begin{gathered}
Y_{t}=\alpha_{1}+\sum_{i=1}^{n} \beta_{i} X_{t-i}+\sum_{i=1}^{m} \gamma_{i} Y_{t-j}+e_{1 t} \\
X_{t}=\alpha_{2}+\sum_{i=1}^{n} \theta_{i} X_{t-i}+\sum_{i=1}^{m} \delta_{i} Y_{t-j}+e_{.2}
\end{gathered}
$$

where $e_{y t}$ and $e_{x t}$ are uncorrelated white noise error terms. The direction of causality of $Y_{t}$ and $X_{t}$ could result in any of these causes: a bi-directional causality

$$
F=\frac{R S S_{R}-R S S_{U} / m}{R S S_{U} / n-k}
$$

Which follows the $\mathrm{F}_{\mathrm{m}, \mathrm{n}-\mathrm{k}}$ distribution and $\mathrm{K}$ $=m+n+1$. Should the computed F-value exceed the F-critical value, the null hypothesis is rejected and concludes that $X_{t}$ cause $Y_{t}$. Rss $\mathrm{u}$ and $\mathrm{Rss}_{\mathrm{R}}$ represent the sum of squared residual from the unrestricted and restricted equations and a unidirectional pairwise causality (Asteriou and Hall, 2011: 322). The study adopts the normal Wald F- statistic on coefficient restriction as follows: respectively. Therefore as stated by Asteriou and Hall, (2011: 321) the statistical inference from these exercises enabled the study to estimate the model such as that some coefficients that appear to be insignificant can be dropped, in order to lead to models that might have an underlying consistent theory. 


\section{Results and Discussion}

The variables' unit root results were more stationary at first difference, I(1), $1 \%$ critical level except LSnrt, LGfcf and Gdprt at $5 \%$ critical (significant) level (see table 1 under appendix),with some significance at levels I $(0)$. This implies rejection of the null hypothesis and contending that the series over time have constant means, variances and covariance that are independent of time. The subsequent Granger Causality tests (see table 2) reasonably conform with our model a-priori expectation as the model achieved unidirectional causalities from the independent variables to the dependent variables for many control variables in the three equations. Bilateral causalities were also achieved between LSnrt and Rstgdp; between Upgt and Gfcf; and between Upgt and Gdprt respectively.

Table 1: Unit Root Test

\begin{tabular}{|l|c|c|}
\hline Variables & $\begin{array}{c}\text { ADF: First Difference } \\
\text { (Intercept and Trend) }\end{array}$ & $\begin{array}{c}\text { Remark: Order of } \\
\text { integration }\end{array}$ \\
\hline RSTGDP & -7.355613 & $\mathrm{I}(1)$ \\
HDI & -6.449291 & $\mathrm{I}(1)$ \\
SNRT & -3.857890 & $\mathrm{I}(1)$ \\
INRT & -6.238692 & $\mathrm{I}(1)$ \\
LGFCF & -3.967296 & $\mathrm{I}(1)$ \\
LMBSN & -3.620270 & $\mathrm{I}(0)$ \\
GCPTVDX & -6.131107 & $\mathrm{I}(1)$ \\
PRDX & -3.769072 & $\mathrm{I}(0)$ \\
UPGT & -4.345666 & $\mathrm{I}(0)$ \\
INFRT & -3.414902 & $\mathrm{I}(0)$ \\
GDPRT & -5.274967 & $\mathrm{I}(0)$ \\
PCTAX & -5.285849 & $\mathrm{I}(1)$ \\
FSDGDP & -7.113547 & $\mathrm{I}(1)$ \\
UMRT & -4.955415 & $\mathrm{I}(1)$ \\
MPR & --6.848032 & $\mathrm{I}(1)$ \\
RQTY & -6.975278 & $\mathrm{I}(1)$ \\
\hline
\end{tabular}


Table 2: Abridged Granger Causality Test Results (significant results in bold)

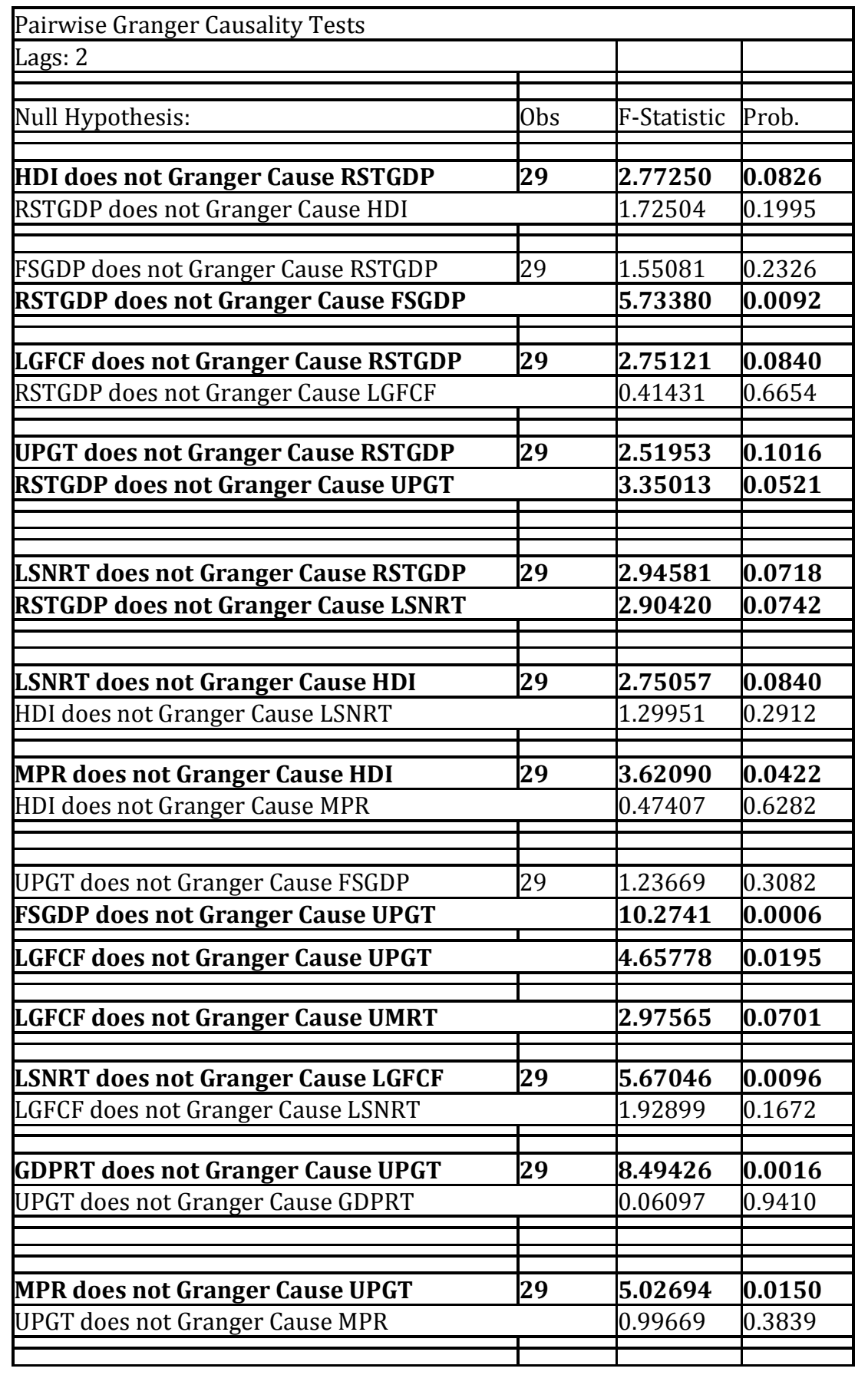

The diagnostics result from the two stage least square, for each of the equations produce reasonable good fit (see table 3(ac)). The Rstgdp equation produced $47 \%$ coefficient of correlation, and $40 \%$ coefficient of determination (overall fit) implying that the explanatory variablesHdi, Fsgdp, Gfcf and Upga explain 40\% variations in the Rstgdp; The Hdi equation produced $36 \%$ and $31 \%$ coefficient of 
correlation and determination respectively, implying that the explanatory variablesRstgdp, Gdprt and Umrt explained 31\% of variations in the Hdi. The Fsgdp equation produced $87.8 \%$ and $86.7 \%$ for coefficient of correlation and coefficient of determination respectively, implying that the explanatory variable-Rstgdp, Snrt and Mpr explained $86.7 \%$ of variation in Fsgdp.

Table 3 (a): Two stage least square result: Rstgdp Equation

\begin{tabular}{|c|c|c|c|c|}
\hline \multicolumn{3}{|c|}{ Dependent Variable: RSTGDP } & & \\
\hline \multicolumn{4}{|c|}{ Method: Two-Stage Least Squares } & \\
\hline \multicolumn{5}{|c|}{ Instrument specification: UPGT GDPRT-1 RQTY SNRT-1 MPR GFCF-1 HDI-1 } \\
\hline \multicolumn{4}{|c|}{ Constant added to instrument list } & \\
\hline Variable & Coefficient & Std. Error & t-Statistic & Prob. \\
\hline $\mathrm{C}$ & 0.406043 & 0.694256 & 0.584861 & 0.5627 \\
\hline HDI & -1.348197 & 0.794645 & -1.696603 & 0.0995 \\
\hline FSGDP-1 & -0.149731 & 0.038412 & -3.898056 & 0.0005 \\
\hline LGFCF & 0.168745 & 0.040798 & 4.136091 & 0.0002 \\
\hline \begin{tabular}{|l|} 
UPGT \\
\end{tabular} & -0.061204 & 0.124122 & -0.493097 & 0.6253 \\
\hline R-squared & 0.470645 & \multicolumn{2}{|c|}{ Mean dependent var } & 1.373784 \\
\hline Adjusted R-squared & 0.404476 & \multicolumn{2}{|c|}{ S.D. dependent var } & 0.164610 \\
\hline S.E. of regression & 0.127030 & \multicolumn{2}{|c|}{ Sum squared resid } & 0.516370 \\
\hline F-statistic & 9.100935 & \multicolumn{2}{|c|}{ Durbin-Watson stat } & 1.477985 \\
\hline Prob(F-statistic) & 0.000050 & \multicolumn{2}{|c|}{ Second-Stage SSR } & 0.388039 \\
\hline J-statistic & 6.371732 & \multicolumn{2}{|c|}{ Instrument rank } & 8 \\
\hline $\operatorname{Prob}(\mathrm{J}$-statistic) & 0.094861 & & & \\
\hline
\end{tabular}

Table 3 (b): Hdi Equation

\begin{tabular}{|c|c|c|c|c|}
\hline \multicolumn{3}{|c|}{ Dependent Variable: HDI } & & \\
\hline \multicolumn{5}{|c|}{ Method: Two-Stage Least Squares } \\
\hline \multicolumn{5}{|c|}{ Instrument specification: UPGT GDPRT-1 RQTY SNRT MPR LGFCF-1 HDI } \\
\hline \multicolumn{2}{|l|}{-1} & & & \\
\hline \multicolumn{5}{|c|}{ Constant added to instrument list } \\
\hline Variable & Coefficient & Std. Error & t-Statistic & Prob. \\
\hline $\mathrm{C}$ & -0.423416 & 0.254762 & -1.662006 & 0.1060 \\
\hline RSTGDP & 0.516823 & 0.195877 & 2.638506 & 0.0126 \\
\hline GDPRT & 0.012216 & 0.003695 & 3.305912 & 0.0023 \\
\hline UMRT & -0.003374 & 0.005608 & -0.601544 & 0.5516 \\
\hline R-squared & 0.363168 & \multicolumn{2}{|c|}{ Mean dependent var } & 0.313384 \\
\hline Adjusted R-squared & 0.305275 & \multicolumn{2}{|c|}{ S.D. dependent var } & 0.103036 \\
\hline S.E. of regression & 0.085881 & \multicolumn{2}{|c|}{ Sum squared resid } & 0.243393 \\
\hline F-statistic & 9.635546 & \multicolumn{2}{|c|}{ Durbin-Watson stat } & 0.921312 \\
\hline Prob(F-statistic) & 0.000103 & \multicolumn{2}{|c|}{ Second-Stage SSR } & 0.168991 \\
\hline J-statistic & 22.91240 & \multicolumn{2}{|c|}{ Instrument rank } & 8 \\
\hline $\operatorname{Prob}(J$-statistic $)$ & 0.000132 & & & \\
\hline
\end{tabular}




\section{Table 3 (c): Fsgdp Equation}

\begin{tabular}{|c|c|c|c|c|}
\hline \multicolumn{3}{|c|}{ Dependent Variable: FSGDP } & & \\
\hline \multicolumn{5}{|c|}{ Method: Two-Stage Least Squares } \\
\hline \multicolumn{5}{|c|}{ Instrument specification: UPGT GDPRT-1 RQTY SNRT-1 MPR GFCF-1 HDI } \\
\hline \multicolumn{4}{|c|}{ Constant added to instrument list } & \\
\hline & & & & \\
\hline Variable & Coefficient & Std. Error & t-Statistic & Prob. \\
\hline$\overline{\mathrm{C}}$ & -1.167879 & 1.242145 & -0.940211 & 0.3539 \\
\hline RSTGDP & -1.331764 & 1.167372 & -1.140823 & 0.2622 \\
\hline LSNRT & 0.419716 & 0.067401 & 6.227109 & 0.0000 \\
\hline MPR & 0.087845 & 0.025901 & 3.391541 & 0.0018 \\
\hline R-squared & 0.877987 & \multicolumn{2}{|c|}{ Mean dependent var } & 2.791351 \\
\hline Adjusted R-squared & 0.866895 & \multicolumn{2}{|c|}{ S.D. dependent var } & 1.314739 \\
\hline S.E. of regression & 0.479663 & \multicolumn{2}{|c|}{ Sum squared resid } & 7.592528 \\
\hline F-statistic & 73.82422 & \multicolumn{2}{|c|}{ Durbin-Watson stat } & 1.136081 \\
\hline Prob(F-statistic) & 0.000000 & \multicolumn{2}{|c|}{ Second-Stage SSR } & 11.27176 \\
\hline J-statistic & 12.35534 & \multicolumn{2}{|c|}{ Instrument rank } & 8 \\
\hline $\operatorname{Prob}(\mathrm{J}$-statistic) & 0.014896 & & & \\
\hline
\end{tabular}

Table 4: Three Stage least Square Result

\begin{tabular}{|c|c|c|c|c|}
\hline \multicolumn{3}{|l|}{ System: Real Estate } & & \\
\hline \multicolumn{5}{|c|}{ Estimation Method: Three-Stage Least Squares } \\
\hline \multirow{2}{*}{\multicolumn{5}{|c|}{ Total system (balanced) observations 111}} \\
\hline & & & & \\
\hline & Coefficient & Std. Error & t-Statistic & Prob. \\
\hline $\mathrm{C}(1)$ & 0.986563 & 0.501523 & 1.967134 & 0.0520 \\
\hline $\mathrm{C}(2)$ & -0.769086 & 0.653056 & -1.177673 & 0.2418 \\
\hline $\mathrm{C}(3)$ & -0.117228 & 0.033233 & -3.527448 & 0.0006 \\
\hline $\mathrm{C}(4)$ & 0.150563 & 0.034209 & 4.401303 & 0.0000 \\
\hline $\mathrm{C}(5)$ & 0.054422 & 0.087306 & 0.623344 & 0.5345 \\
\hline $\mathrm{C}(6)$ & -0.415432 & 0.210712 & -1.971563 & 0.0515 \\
\hline $\mathrm{C}(7)$ & 0.512229 & 0.160729 & 3.186917 & 0.0019 \\
\hline $\mathrm{C}(8)$ & 0.009882 & 0.003074 & 3.214482 & 0.0018 \\
\hline $\mathrm{C}(9)$ & -0.001962 & 0.004437 & -0.442085 & 0.6594 \\
\hline $\mathrm{C}(10)$ & -0.587525 & 1.130233 & -0.519826 & 0.6044 \\
\hline $\mathrm{C}(11)$ & -1.723674 & 1.058183 & -1.628900 & 0.1065 \\
\hline $\mathrm{C}(12)$ & 0.423944 & 0.061921 & 6.846510 & 0.0000 \\
\hline $\mathrm{C}(13)$ & 0.080167 & 0.023906 & 3.353422 & 0.0011 \\
\hline \multicolumn{2}{|c|}{ Determinant residual covariance } & $7.83 \mathrm{E}-06$ & & \\
\hline \multicolumn{5}{|c|}{ Equation: RSTGDP $=\mathrm{C}(1)+\mathrm{C}(2) * \mathrm{HDI}+\mathrm{C}(3) * \mathrm{FSGDP}-1+\mathrm{C}(4) * \mathrm{LGFCF}+$} \\
\hline \multicolumn{5}{|l|}{$\mathrm{C}(5) * \mathrm{UPGT}$} \\
\hline \multicolumn{5}{|c|}{ Instruments: UPGT GDPRT-1 RQTY SNRT-1 MPR GFCF-1 HDI C } \\
\hline \multicolumn{5}{|l|}{ Observations: 37} \\
\hline R-squared & 0.456098 & Mean de & dent var & 1.373784 \\
\hline Adjusted R-squared & 0.388110 & S.D. dep & ent var & 0.164610 \\
\hline
\end{tabular}




\begin{tabular}{|c|c|c|c|}
\hline S.E. of regression & 0.128763 & Sum squared resid & 0.530560 \\
\hline Durbin-Watson stat & 1.272103 & & \\
\hline \multicolumn{4}{|c|}{ Equation: HDI $=\mathrm{C}(6)+\mathrm{C}(7) * \mathrm{RSTGDP}+\mathrm{C}(8) * \mathrm{GDPRT}+\mathrm{C}(9) * \mathrm{UMRT}$} \\
\hline \multicolumn{4}{|c|}{ Instruments: UPGT GDPRT-1 RQTY SNRT-1 MPR GFCF-1 HDI C } \\
\hline \multicolumn{4}{|l|}{ Observations: 37} \\
\hline R-squared & 0.354759 & Mean dependent var & 0.313384 \\
\hline Adjusted R-squared & 0.296101 & S.D. dependent var & 0.103036 \\
\hline S.E. of regression & 0.086446 & Sum squared resid & 0.246607 \\
\hline Durbin-Watson stat & 0.772807 & & \\
\hline \multicolumn{4}{|c|}{ Equation: FSGDP $=\mathrm{C}(10)+\mathrm{C}(11) * \mathrm{RSTGDP}+\mathrm{C}(12) * \mathrm{LSNRT}+\mathrm{C}(13) * \mathrm{MPR}$} \\
\hline \multicolumn{4}{|c|}{ Instruments: UPGT GDPRT-1 RQTY SNRT-1 MPR GFCF-1 HDI C } \\
\hline \multicolumn{4}{|l|}{ Observations: 37} \\
\hline R-squared & 0.873012 & Mean dependent var & 2.791351 \\
\hline Adjusted R-squared & 0.861468 & S.D. dependent var & 1.314739 \\
\hline S.E. of regression & 0.489345 & Sum squared resid & 7.902129 \\
\hline Durbin-Watson stat & 1.163341 & & \\
\hline
\end{tabular}

The regression estimations obtained through the two stage least square approach were reasonably improved upon by the three stage systems approach (see table 4). Therefore, the regression result for the three stage systems produces positive significant causal relationship between $G f c f$, Upgt with Rstgdp, implying that $1 \%$ increase in gross fixed capital formation ( $G f f$ ) ceteris paribus generates proportionately $15 \%$ increase in real estate ratio to gross domestic product. Similarly, a $1 \%$ increase in urban population growth rate (Upgr) ceteris paribus generates proportionately $5 \%$ increase in real estate ratio to GDP. The result also reveals significant causal relationship between Rstgdp, Grgdp, Umrt with Hdi. This implies that a $1 \%$ increase in real estate gross domestic product (Rstgdp), gross domestic growth (Gdprt), unemployment rate (Umrt), ceteris paribus generates proportionately $51 \%$ and $0.9 \%$ increase in Human development index and $0.2 \%$ decrease in Human development index (Hdi) respectively. The result also reveals causal relations between Snrt, Mpr with Fsgdp. By implication, a $1 \%$ increase in savings rate and monetary policy rate ceteris paribus generates proportionately $42 \%$ and $8 \%$ increase in financial sector gross domestic product (Fsgdp) respectively.
The study found that Hdi, gross fixed capital formation and savings rate granger cause real estate gross domestic product. It appears that the quality of life, the level of capital accumulation level and the associated saving rate, if improved upon, could turn around the fortunes of Nigeria's real estate market's contribution to gross domestic product. Similarly, real estate development influences financial development and urban population growth rate. It conforms to economic intuition that well-articulated real estate development could revolutionanise a nation's financial architecture through securitization, as evidenced by developments in the western economies and emergent markets of Singapore, United Arab Emirate (Dubai), Brazil, etc, through securitization of the real estate sector.

The result also found that the savings rate and monetary policy rate influence the human development index. It requires that the government monetary policy should be such that would improve savings habit, reduce inflation and hence transmitted towards improving the quality of life of the average Nigerian. This can be achieved through fiscal mechanism. In triangular feedback manner, financial development influences gross fixed capital formation and urban population growth, which the study identified as critical for real estate 
development. The study found that savings rate influences gross fixed capital formation, which means that the economy must encourage savings at all cost to boost capital formation. Also, that gross domestic product growth influences urban population growth rate which affirms the theory that positive association exists between urbanization and per capita income in the development process. Lower unemployment rate boosts the savings capacity and capital formation, which suggestively increases high investment in real estate development. From the regression findings, the results suggests that gross fixed capital formation and increases in urban population growth rate improve investment in real estate market in Nigeria.

\section{Conclusion and Recommendation}

That real estate infrastructures perform a critical role in a country's welfare (quality of life) is always recognized, as it directly affects not only the well-being of the citizenry, but also influences the performance of other sectors of the economy.

This study used the 3-stage system model to examine the causal relationship between real estate development, financial development and economic development. The Granger causality test produced unidirectional causality pairwise among variables that correlate with the real estate sector. The result of the two stage regression amplified in the 3-stage least square for real estate equation reveals causal impact of gross capital formation on real estate gross domestic product; gross domestic product growth rate, and unemployment rate on human development index; and the impact of savings rate and monetary policy rate on financial sector ratio to gross domestic product in Nigeria.

Following these impactful relationships, this study recommends that the government should improve the macroeconomic environment to attract more private capital, adopt a low MPR regime to direct resources to long term ventures such as the real estate sector. The study suggests financial matching principle, where market driven financial institutions committed to long term funding, such as the Sovereign Wealth Funds, Pension Funds, etc invest in mortgages and real estate development; the government should commit higher capital budgetary allocations for infrastructural development. The monetary authorities should evolve discriminatory monetary policy rate that favours the real estate sector.

\section{Reference}

1. Adetiloye, K A (2013), "The National Housing Fund, Mortgage Finance and Capital Formation in Nigeria”, International Journal of Business and Social Research, Vol. 3 No 7: $43-53$

2. Asteriou, D. and Hall, S.G. (2011), Applied Econometrics, Second Edition, Palgrave Macmillan: Pp 319-354.

3. Bischoff, O (2012), "Explaining regional variation in equilibrium real estate prices and income." Journal of Housing Economics, Vol. 21: 1-15.

4. Brueggeman, W B and Fisher, J. D. (2005), Real Estate Finance and Investments, Twelfth edition, Mcgraw-Hill Irwin: 228-251.

5. Colwell and Trefzger, (2013) "The Economics of Real Estate Principles" http://business.illinois.edu/over/08-22.pdf assessed on 5th June, 2013.

6. Deller, SC, Tsai,TH Marcouiller, DW and English DBK (2001), "The Role of Amenities and Quality of Life in Rural Economic Growth.", American Journal of Agricultural Economics, Vol. 83, (2001): 352-365

7. Eke, PO. and Ashamu,SO(2009), Portfolio Management and Strategies, First Edition, Eagles Concept, Lagos: 169-197.

8. Federal Government of Nigeria (2011), National Housing Policy, 2011. 
9. Goldsmith, RW(1969), Financial Structure and Development, New Haven, Yale University Press

10. Goldsmith, RW (1971), "The Development of Financial Institutions during Post-War Period", Banca Nationale de Lavoro, Quarterly Review, June: 129-192

11. Grossman, G and Helpman, E1991), "Quality Ladders in the Theory of Growth", Review of Economic Studies 58: 43-61.

12. Gujarati, D N and Porter, D C (2009), Basic Econometrics, fifth edition, McGraw Hill: 34-54.

13. Henderson, JV. and Ioannides Y (1979), "A model of housing tenure choice", American Economic Review, Vol. 73: 98-113

14. Jayaraman, $\mathrm{P}$ and Gebremedhin, $\mathrm{T}$ (2013) "A Non-Spatial Analysis of the Role of Residential Real Estate Investment in the Economic Development of the Northeast Region of the United States" Being a selected paper presented at the Southern Agricultural Economics Association (SAEA) Annual Meeting, Orlando, Florida, 3-5 February.

15. Karagol Erdal (2002) "External Debt and Economic Growth Relationship Using the Simultaneous Equations", VI METU, Middle East Technical University, The International Economic Conference in Economics, 11-14 September, Ankara, Turkey.

16. Kmenta, J (1997) Elements of Econometrics, second edition, Ann Arbor, The University of Michigan Press: 651-731.

17. Koutsoyiannis, A(1977), Theory of Econometrics, Second Edition, (Macmillan): 331-511.

18. Miller, NG and Geltner, DM(2005), Real Estate Principles for the new Economy, Thomson South-Western:2-212.

19. National Bureau of Statistics, (2012), "Ist Quarter GDP Report" www.nationalbureaustatistics.gov assessed $7^{\text {th }}$ June, 2013.
20. Nubi, NO (1991), "Housing Finance in Nigeria- need for re-engineering", www.housing finance.org/../Africa.

21. Ojo, Ade T (2010), The Nigerian Maladapted Financial System: Reforming Tasks and Development Dilemma in Nigeria, Charted Institute of Banker Press, Nigeria: 1-70.

22. Okupe, L(2000), "The Role of Private Sector in housing Delivery in Nigeria", A seminar paper on Effective approach to housing delivery in Nigeria, organised by Nigerian Institute of Building. Ibadan, Nigeria.

23. Oyinlola, MA (2012), "Model Estimation", Macroeconomic Model Workshop, Centre for Econometrics and Allied Research (CEAR), University of Ibadan.

24. Plaut, SE(1987), "The timing of housing tenure transition", Journal of Urban Economics, Vol. 21:312-322

25. Romer, P(1986), "Increasing Returns and Long-Run growth", Journal of Political Economy 94: 1002-1037

26. Romer, C(1990), "The great Crash and the Onset of the Great Depression", Quarterly Journal of Economics 105(3): 597-624.

27. Sanusi, JO (2003), "Mortgage Financing in Nigeria: issues and challenges" Being Text of a Paper Presented at the $9^{\text {th }}$ John Wood Ekpenyong Memorial Lecture, Organized by the Nigerian Institution of Estate Surveyors and Valuers, January 29, 2003

28. Solow, R(1956) "A contribution to the Theory of Economic Growth", Quarterly Journal of Economics 70 (1): 26-41.

29. Ukpong, S (2013), "We have seen demand surge for our apartments", The Interview, www.businessdayonline.com accessed on $8^{\text {th }}$ May, 2013. 
30. Wiedemer, J P and Goeters, JE (2003), Real Estate Investments, $6^{\text {th }}$ Edition, Centage Learning

31. Windapo, A (2000), "Constrain of the Construction Industry in an Unstable Economy", A seminar paper on effective approach to housing Delivery, organised by Nigerian Institute of Building. Ibadan.
32. World Bank (2010), "Reforming the international financial architecture", World Economic and Social Survey 2010: Chapter $V, 103-131$

33. Yau, Jot K, Schneeweis, $\mathrm{T}$, Robinson, $\mathrm{T}$. R., and Weiss, L. R. (2007), "Alternative Investments Portfolio Management" in Managing Investment Portfolio: A Dynamic Process, Third Edition, Maginn, L. John et al, edited, John Wiley and Sons, Inc.:477-578 